(c) American Dairy Science Association, 2005.

\title{
Effect of Length of Cut and Kernel Processing on Use of Corn Silage by Lactating Dairy Cows
}

\author{
K. M. Cooke and J. K. Bernard \\ Department of Animal and Dairy Science, The University of Georgia, Tifton 31793-0748
}

\begin{abstract}
Forty Holstein cows were used in an 8-wk randomized block design trial to determine the effects of theoretical length of cut (TLC) and kernel processing (KP) of whole plant corn silage on nutrient intake and digestibility, milk yield, and milk composition. Corn was harvested at three-quarters milk line stage of maturity at TLC of 1.90 or $2.54 \mathrm{~cm}$. At each TLC, corn was KP at either 2 or $8 \mathrm{~mm}$ roll clearance. The control was harvested at $1.90 \mathrm{~cm}$ without KP. Corn silage provided $38 \%$ of the dietary dry matter (DM) in the experimental diets. Intake of DM and nutrients was similar among treatments. Apparent digestibility of DM and acid detergent fiber (ADF) increased with increasing TLC. Fiber digestibility was improved by KP compared with unprocessed corn silage. Starch digestibility was greater for corn silage KP at 2 vs. $8 \mathrm{~mm}$. Apparent digestibility of $\mathrm{DM}$, crude protein, and ADF was lowest for the diet containing silage harvested at $2.54 \mathrm{~cm}$ TLC and KP at $8 \mathrm{~mm}$, resulting in an interaction of TLC and KP. No differences were observed in DM intake (DMI) among treatments. An interaction of TLC and KP was observed, however, for yield of milk protein and energycorrected milk (ECM) and efficiency of converting DMI to ECM because of lower yield for diets containing silage harvested at $2.54 \mathrm{~cm}$ TLC and KP at $8 \mathrm{~mm}$. Results of this trial indicate that as TLC increases, aggressive $\mathrm{KP}$ is necessary to maintain nutrient digestibility and performance of lactating dairy cows.
\end{abstract}

(Key words: corn silage, kernel processing, theoretical length of cut)

Abbreviation key: KP = kernel processing, TLC = theoretical length of cut, $\mathbf{1 . 9 5 C}=$ corn silage chopped at $1.95 \mathrm{~cm}$ with no kernel processing, $1.95 \mathrm{M}=$ corn silage chopped at $1.95 \mathrm{~cm}$ with 2 -mm kernel processing, $\mathbf{1 . 9 5 P}=$ corn silage chopped at $1.95 \mathrm{~cm}$ with $8-\mathrm{mm}$ kernel processing, 2.54M = corn silage chopped at 2.54

Received February 16, 2004.

Accepted August 2, 2004.

Corresponding author: J. K. Bernard; e-mail: jbernard@tifton.uga. edu. cm with 2-mm kernel processing, 2.54P = corn silage chopped at $2.54 \mathrm{~cm}$ with $8-\mathrm{mm}$ kernel processing.

\section{INTRODUCTION}

Over the past decade, there has been increased interest in kernel processing (KP) of whole plant corn silage using forage harvesters equipped with onboard processing rolls. Kernel processing at 1 to $2 \mathrm{~mm}$ has been shown to increase starch digestibility (Rojas-Bourrillon et al., 1987; Johnson et al., 1996; Bal et al., 2000) and decrease particle size of corn silage by 15 to $30 \%$ (Schurig and Rodel, 1993; Roberge et al., 1998). The reduced particle size of the resulting corn silage does not provide adequate physically effective fiber to maintain rumen health, so it is recommended that the theoretical length of cut (TLC) be increased to $1.9 \mathrm{~cm}$ (Johnson et al., 2003b).

Increasing the TLC does improve the physical effectiveness of KP corn silage, but it is not clear whether increasing the TLC further would be beneficial or lead to lower fiber digestibility and greater sorting. Increasing the TLC decreases fuel requirements and increases the rate of harvest (Johnson et al., 2003b). Kernel processing increases machinery power requirements by 7 to $15 \%$ and slows the rate of harvest considerably (Schurig and Rodel, 1993; Roberge et al., 1998). In some situations, producers or custom harvesters open the roll clearance to less aggressively process so they can save fuel and increase harvesting rate. Savoie (1997) reported that $97 \%$ of kernels were cracked or broken when the roll clearance was set at $6 \mathrm{~mm}$, compared with $82 \%$ when the KP was not activated, and suggested that adequate processing could be obtained when the roll clearance was set between 4 and $6 \mathrm{~cm}$. Straub et al. (1996) reported a $1.3-\mathrm{kg} / \mathrm{d}$ increase in milk yield for cows fed diets containing corn silage with a $1.36-\mathrm{cm}$ TLC processed at $4.5 \mathrm{~mm}$ compared with unprocessed corn silage.

Increasing the TLC beyond $1.9 \mathrm{~cm}$ and increasing roll clearance of the KP may potentially reduce nutrient digestibility and animal performance. A greater proportion of kernels would be cracked or broken, which would presumably reduce starch digestibility compared with corn that was $\mathrm{KP}$ at 1 to $2 \mathrm{~mm}$. The larger particle 
Table 1. Ingredient composition of diets containing corn silage chopped at different theoretical lengths of cut (TLC) with or without kernel processing (KP).

\begin{tabular}{lc}
\hline Ingredient & $\%$ of DM \\
\hline Corn silage $^{1}$ & 38.67 \\
Steam flaked corn & 18.21 \\
Brewers grain, wet & 12.92 \\
Whole cottonseed & 6.49 \\
Alfalfa hay & 6.11 \\
Urea & 0.31 \\
Base concentrate $^{2}$ & 10.68 \\
Energy-protein supplement $^{3}$ & 6.61 \\
\hline
\end{tabular}

${ }^{1}$ Corn silage treatments included 1) $1.95 \mathrm{~cm}$, no KP; 2) $1.95 \mathrm{~cm}, 2$ $\mathrm{mm} \mathrm{KP}$; 3) $1.95 \mathrm{~cm}, 8-\mathrm{mm} \mathrm{KP}$; 4) $2.54 \mathrm{~cm}, 2-\mathrm{mm} \mathrm{KP}$; and 5) $2.54 \mathrm{~cm}$, 8-mm KP.

${ }^{2}$ Base concentrate contained (\% of mix, DM basis) $38.10 \%$ soybean meal, $17.33 \%$ cottonseed hulls, $17.14 \%$ citrus pulp, $6.67 \%$ limestone, $5.71 \%$ sodium bicarbonate, $3.43 \%$ vitamin-trace mineral premix, 2.29\% Diamond V XP yeast (Diamond V Mills, Cedar Rapids, IA), $2.10 \%$ dicalcium phosphate, $1.90 \%$ potassium carbonate, $1.52 \%$ magnesium oxide, and $1.14 \%$ potassium-magnesium-sulfate.

${ }^{3}$ Energy-protein supplement contained (\% of mix, DM basis) $53.85 \%$ soybean meal, $23.08 \%$ ground corn, $15.38 \%$ calcium salts of longchain fatty acids, $4.62 \%$ dicalcium phosphate, and $3.08 \%$ potassium carbonate.

resulting from longer TLC and less aggressive KP would have less surface area upon which fibrolytic microorganisms could attach, potentially reducing fiber digestion. If both starch and fiber digestibility were reduced, even slightly, less energy would be available in support of milk synthesis. This trial was conducted to determine the effects of increasing TLC and less aggressive KP of whole plant corn silage on nutrient intake, digestibility, and performance of lactating dairy cows.

\section{MATERIALS AND METHODS}

Forty Holstein dairy cows (18 primiparous and 22 multiparous) in midlactation (144 \pm 45 DIM and $34 \pm$ $6 \mathrm{~kg} / \mathrm{d}$ of milk) were used in a randomized block design trial with an incomplete $3 \times 2$ factorial arrangement of treatments. The 5 treatments consisted of $1.95-\mathrm{cm}$ corn silage with no kernel processing (1.95C; control), 1.95$\mathrm{cm}$ corn silage with 2 -mm processor roll clearance (1.95P; aggressively processed), 1.95-cm corn silage with 8-mm processor roll clearance $(\mathbf{1 . 9 5 M}$; moderately processed), $2.54-\mathrm{cm}$ corn silage with $2-\mathrm{mm}$ processor roll clearance $(\mathbf{2 . 5 4 P})$, and $2.54-\mathrm{cm}$ corn silage with 8-mm processor roll clearance $(\mathbf{2 . 5 4 M})$. The trial was conducted from January 16, 2003 to March 7, 2003. Cows were housed in a free stall barn at the University of Georgia Dairy Research Center in Tifton. Experimental diets contained approximately $38 \%$ forage from unprocessed or KP corn silage, $6 \%$ alfalfa hay, and 56\% concentrate (DM basis, Table 1).
Corn (Pioneer 33J56, Pioneer Hi-Bred International, Inc., Des Moines, IA) was planted on March 31, 2002 in a Tift loam soil. Corn was irrigated with dairy waste effluent to provide nutrients with additional fresh water to meet water requirements. Corn was harvested from July 10, 2002 to July 12, 2002 at three-quarters milk line stage of maturity and 37\% DM from a uniform section of the field. Processed corn silage was harvested using a John Deere 3975 pull-type forage harvester (Deere and Company, Moline, IL) equipped with an onboard kernel processor. Processing rolls with a diameter of $20.3 \mathrm{~cm}$ were located between the cutterhead with 24 knives. The TLC was adjusted by changing the speed of feeder rolls to provide TLC of 1.95 or $2.54 \mathrm{~cm}$. Corn silage was harvested and processed at $1.95 \mathrm{~cm}$, with 2- and 8-mm processor roll clearance, and 2.54 $\mathrm{cm}$, with 2 - and $8-\mathrm{mm}$ processor roll clearance. The control corn silage of $1.95-\mathrm{cm}$ unprocessed corn silage was harvested using a Claas 880 self-propelled forage harvester (Claas of America, Columbus, IN) set for a TLC of $1.95 \mathrm{~cm}$ with the kernel processor removed. Chopped corn was stored in 2.4-m plastic silage bags (Kelly Ryan, Blaine, NE) and allowed to ferment approximately 5 mo before beginning the feeding trial.

The trial consisted of a 2 -wk standardization period followed by a 6 -wk experimental period. Cows were trained to operate electronic gate feeders (American Calan, Northwood, NH) before the standardization period began. Cows were fed a TMR once daily $(0800 \mathrm{~h})$ in amounts to provide approximately $10 \%$ orts for ad libitum consumption. The TMR was pushed up a minimum of $4 \times$ each day. Amounts of TMR offered and refused were recorded daily. Cows were milked $2 \times$ each day at approximately 0400 and $1500 \mathrm{~h}$, and daily milk yield was recorded electronically (Alpro, DeLaval, Kansas City, MO). All protocols were reviewed and approved by the University of Georgia Institute of Animal Care and Use Committee.

\section{Sample Collection and Analysis}

Milk samples were collected from 2 consecutive evening and morning milkings during each week of the trial. Milk samples were shipped to Southeast Milk, Inc. in Belleview, FL for analyses of fat, protein, and somatic cell concentrations.

Corn silage treatments, feed ingredients, experimental diets, and orts were collected $3 \times / \mathrm{wk}$. Samples were composited each week of the trial and stored at $0^{\circ} \mathrm{C}$ until analysis. Composite samples were dried at $60^{\circ} \mathrm{C}$ for $72 \mathrm{~h}$ and ground to pass through a 1-mm screen using a Wiley Mill (Arthur B. Thomas, Philadelphia, PA). Samples were analyzed for DM (forages [Goering and Van Soest, 1970]; grains, mixed feeds, concentrates, 
and byproducts [AOAC, 1990]), CP (Leco FP-528 Nitrogen Analyzer, St. Joseph, MI), ADF (AOAC, 1990), NDF and lignin (Goering and Van Soest, 1970), starch (Holm et al., 1986), and pH (Mettler DL12 Titrator, Columbus, $\mathrm{OH})$.

Concentrations of fermentation end products in experimental silages were determined by blending $25 \mathrm{~g}$ of wet sample with $200 \mathrm{~mL}$ of distilled water and filtering. The $\mathrm{pH}$ was determined by introducing $30 \mathrm{~mL}$ of the extract into a Mettler DL12 Titrator (Mettler-Toledo, Inc., Columbus, $\mathrm{OH}$ ) and titrating with $0.1 \mathrm{~N}$ $\mathrm{NaOH}$ to a $\mathrm{pH}$ of 6.5. Ammonia concentrations were determined using a Tecator Kjeltec Auto 1030 Analyzer (Tecator, Eden Prairie, MN) by titrating a mix of 50 $\mathrm{mL}$ of distilled water plus $50 \mathrm{~mL}$ of extract with $0.1 \mathrm{~N}$ HCL. Lactic acid concentrations were determined on a diluted sample of extract (1:4 of extract to distilled water) using a YSI Select Biochemistry Analyzer (YSI, Inc., Yellow Springs, OH). Concentrations of acetic, propionic, butyric, and isobutyric acids were determined by filtering $5 \mathrm{~mL}$ of extract through a $2-\mu \mathrm{m}$ acetate microfilter and a 1.2- $\mu \mathrm{L}$ subsample was injected into a Shimadzu GC-14A gas chromatograph (Shimadzu GC14A, Columbia, MD) using a Supelco column packed with Carbowax 20M8.

Particle size of corn silage and TMR samples was determined using the Penn State Forage Particle Size Separator as outlined by Heinrichs (1996). Representative subsamples of each composited sample were weighed to ensure that at least $250 \mathrm{~g}$ of sample were wet sieved through 3 plastic separator boxes. The diameters of screens used were $1.95 \mathrm{~cm}$ for the upper sieve and $0.775 \mathrm{~cm}$ for the middle sieve. Mean particle length of samples was determined by calculating the proportion of sample remaining on each sieve.

During wk 5 of the experimental period, fecal grab samples were collected from a subgroup of 20 cows, 4 from each treatment group on 4 consecutive d at 12-h intervals. Sampling time was advanced by $2 \mathrm{~h}$ each day so that samples were collected at 0500, 0700, 0900, $1100,1700,1900,2100$, and $2300 \mathrm{~h}$. Samples were composited by cow and dried in a forced-air oven at $60^{\circ} \mathrm{C}$ for $72 \mathrm{~h}$. Samples were ground to pass through a 1-mm screen using a Wiley mill and analyzed for DM, CP, $\mathrm{ADF}, \mathrm{NDF}$, lignin, and starch as described previously. Diet, ort, and fecal samples were analyzed for indigestible ADF as an internal marker as described by Cochran et al. (1986)

Body weights were recorded on 2 consecutive days during the standardization period and wk 6 of the experimental period and once during wk 2 and 4 of the experimental period. To minimize variation, all BW were recorded after the evening milking before animals had access to feed or water. Body condition scores were recorded during wk 1,4 , and 6 of the experimental period by 2 independent evaluators according to Edmondson et al. (1989).

Whole blood samples were collected via coccygeal venipuncture during the standardization period, wk 4, and at the end of the trial. Tubes were allowed to clot, and serum was harvested by centrifugation. Samples were analyzed at the University of Georgia Veterinary Diagnostic Laboratory in Tifton for blood urea $\mathrm{N}$ and glucose using a Boehringer Mannheim/Hitachi 912 automated chemistry analyzer (Roche Laboratory Systems, Indianapolis, IN).

\section{Statistical Analysis}

Dry matter intake, milk yield and composition, and BW data were analyzed as a randomized block using PROC MIXED procedures of SAS. The model included effects of covariate, block, treatment, week, and their interactions. The corresponding value from the preliminary period was included as a covariate in the model. The model included cow within treatment as a random variable and week as a repeated measure. The following planned orthogonal contrasts were included in the model: 1) 1.95 vs. $2.54 \mathrm{~cm}$ TLC (1.95C, $1.95 \mathrm{P}$, and $1.95 \mathrm{M}$ vs. $2.54 \mathrm{P}$ and $2.54 \mathrm{M}) ; 2$ ) control vs. $\mathrm{KP}(1.95 \mathrm{C}$ vs. all other treatments); 3) 2 vs. $8 \mathrm{~mm} \mathrm{KP}$ (1.95P and $2.54 \mathrm{P}$ vs. $1.95 \mathrm{M}$ and $2.54 \mathrm{M}$ ); and 4 ) the interaction of TLC and KP (excluding the control). Nutrient intake and apparent digestibility data were analyzed using PROC MIXED procedures of SAS. The model included block and treatment, and cow within treatment was included as a random variable. Orthogonal contrasts, as outlined previously, were also included in the model.

\section{RESULTS AND DISCUSSION}

\section{Chemical Characteristics of Corn Silage and TMR}

The chemical compositions of the corn silage treatments are presented in Table 2. The DM content was slightly lower for the corn silage processed at $2 \mathrm{~mm}$, and CP concentration was numerically lower for KP corn silage than $1.95 \mathrm{C}$. Both $1.95 \mathrm{P}$ and $2.54 \mathrm{M}$ contained slightly more NDF and less starch than $1.95 \mathrm{M}$ and $2.54 \mathrm{P}$.

Changes in the chemical composition of corn silage have been related to KP and TLC in previous trials. Johnson et al. (2002a, 2003b) reported decreased concentrations of DM in KP vs. unprocessed corn silage, whereas other researchers (Rojas-Bourrillon et al., 1987; Andrae et al., 2001; Zobell et al., 2002) have not observed any differences. No differences were observed in the concentration of $\mathrm{CP}$ of $\mathrm{KP}$ vs. unprocessed corn silage in previous trials (Johnson et al., 2002a; Zobell 
Table 2. Chemical composition and particle size of corn silage chopped at different theoretical lengths of cut (TLC) with or without kernel processing (KP).

\begin{tabular}{|c|c|c|c|c|c|}
\hline & $\begin{array}{l}1.95-\mathrm{cm} \\
\text { TLC, } \\
\text { no KP }\end{array}$ & $\begin{array}{l}1.95-\mathrm{cm} \\
\text { TLC, } \\
2-\mathrm{mm} \text { KP }\end{array}$ & $\begin{array}{l}1.95-\mathrm{cm} \\
\text { TLC, } \\
8-\mathrm{mm} \text { KP }\end{array}$ & $\begin{array}{l}2.54-\mathrm{cm} \\
\text { TLC, } \\
2-\mathrm{mm} \mathrm{KP}\end{array}$ & $\begin{array}{l}2.54-\mathrm{cm} \\
\text { TLC, } \\
\text { 8-mm KP }\end{array}$ \\
\hline & \multicolumn{5}{|c|}{$\longrightarrow(\%)$} \\
\hline $\mathrm{DM}$ & 37.5 & 32.2 & 37.3 & 36.8 & 34.9 \\
\hline $\mathrm{CP}$ & 11.1 & 9.9 & 8.7 & 7.9 & 10.0 \\
\hline $\mathrm{NDF}$ & 33.9 & 37.3 & 33.6 & 32.8 & 36.3 \\
\hline $\mathrm{ADF}$ & 20.4 & 22.3 & 19.6 & 19.9 & 21.2 \\
\hline Starch & 35.2 & 33.3 & 38.9 & 38.9 & 35.5 \\
\hline NFC & 48.7 & 46.1 & 51.2 & 52.6 & 46.7 \\
\hline Ash & 3.3 & 3.7 & 3.5 & 3.6 & 4.0 \\
\hline $\mathrm{pH}$ & 3.7 & 4.1 & 4.1 & 4.0 & 4.0 \\
\hline Ammonia & 0.8 & 0.9 & 0.7 & 0.4 & 0.9 \\
\hline Lactic acid & 4.9 & 2.8 & 2.0 & 2.3 & 2.9 \\
\hline Acetic acid & 1.2 & 1.7 & 1.4 & 1.7 & 1.9 \\
\hline \multirow[t]{2}{*}{ Propionic acid } & 0.1 & 0.2 & 0.2 & 0.1 & 0.3 \\
\hline & \multicolumn{5}{|c|}{ - (\% of sample remaining on screen [as-fed basis]) } \\
\hline$>19$ & 18.6 & 6.4 & 13.1 & 12.1 & 25.3 \\
\hline 8 to 19 & 65.6 & 76.2 & 74.1 & 62.7 & 63.3 \\
\hline$<8$ & 15.8 & 17.4 & 12.9 & 25.2 & 11.4 \\
\hline
\end{tabular}

et al., 2002; Johnson et al., 2003c). Kernel processing has been observed to decrease NDF concentrations (Doggett et al., 1998; Johnson et al., 2002a) possibly because of increased concentrations of total alpha-glucosides in the rolled silage (Rojas-Bourrillon et al., 1987). In contrast, Weiss and Wyatt (2000) observed increased NDF concentrations in KP corn silage compared with unprocessed corn silage and attributed the increase in NDF to greater fermentation losses of readily fermentable substrates in the KP corn silage. However, increased starch concentrations have been reported for KP corn (Rojas-Bourrillon et al., 1987; Doggett et al., 1998; Johnson et al., 2003b).

Sudweeks et al. (1979) reported increased concentrations of CP as TLC increased from 0.63 to $1.91 \mathrm{~cm}$. However, most researchers have not observed any difference in CP content of corn silage differing in TLC (Clark and Armentano, 1999; Dhiman et al., 2000). Bal et al. (2000) reported an interaction of TLC and KP for $\mathrm{NDF}, \mathrm{ADF}$, and starch concentrations. In their trial, NDF concentrations increased as TLC increased in KP corn silage. These researchers also noted that the more finely chopped KP corn silage had higher starch concentrations than unprocessed control silage.

Much of the variation in the chemical composition of KP corn silage can be attributed to more uniform sampling techniques of KP corn silage as described by Bal et al. (2000). Depending on particle size, less of the grain fraction would settle out of the silage during sampling providing a more representative sample.
The $\mathrm{pH}$ of $\mathrm{KP}$ corn silage tended to be higher and lactic acid tended to be lower than that of the unprocessed corn silage (Table 2). The higher $\mathrm{pH}$ is consistent with results reported by Dhiman et al. (2000) and Weiss and Wyatt (2000). Kernel processing has been shown to increase lactic acids concentrations compared with unprocessed corn silage in previous studies (Rojas Bourrillon et al., 1987; Johnson et al., 2002a; Johnson et al., 2003c-experiment 2).

As TLC decreased, or the degree of KP increased, the proportion of material retained on the top screen of the Penn State Separator decreased (Table 2), whereas the proportion of material on the bottom pan increased. Aggressive KP resulted in more material on both the middle and bottom screens of the separator. These results are consistent with the treatments applied at harvest. Johnson et al. (2003b) observed similar results with corn silage chopped at 1.11 and $2.78 \mathrm{~cm}$.

The chemical composition of experimental diets is presented in Table 3. The TMR for animals fed silage cut at $2.54 \mathrm{~cm}$ and $\mathrm{KP}$ at $8 \mathrm{~mm}$ was slightly lower in DM content compared with the other TMR (39.9\% vs. $43.2 \%$, respectively). Starch and nonfibrous carbohydrate concentrations were numerically lower for diets containing corn silage $\mathrm{KP}$ at $8 \mathrm{~mm}$. All other nutrient concentrations were similar among treatments. As expected, a higher percentage of the diets containing 2.54$\mathrm{cm}$ TLC corn silage was retained on the top screen of the Penn State Separator. 
Table 3. Chemical composition and particle size of diets containing corn silage chopped at different theoretical lengths of cut (TLC) with or without kernel processing (KP).

\begin{tabular}{|c|c|c|c|c|c|}
\hline & $\begin{array}{l}1.95-\mathrm{cm} \\
\text { TLC, } \\
\text { no KP }\end{array}$ & $\begin{array}{l}1.95-\mathrm{cm} \\
\text { TLC, } \\
2-\mathrm{mm} \mathrm{KP}\end{array}$ & $\begin{array}{l}\text { 1.95-cm } \\
\text { TLC, } \\
\text { 8-mm KP }\end{array}$ & $\begin{array}{l}2.54-\mathrm{cm} \\
\mathrm{TLC}, \\
2-\mathrm{mm} \mathrm{KP}\end{array}$ & $\begin{array}{l}2.54-\mathrm{cm} \\
\mathrm{TLC}, \\
8-\mathrm{mm} \mathrm{KP}\end{array}$ \\
\hline \multirow[b]{2}{*}{ DM } & \multicolumn{5}{|c|}{$-(\%)$} \\
\hline & 43.6 & 43.6 & 43.0 & 42.7 & 39.9 \\
\hline $\mathrm{CP}$ & 17.7 & 17.6 & 18.3 & 17.6 & 18.1 \\
\hline $\mathrm{NDF}$ & 30.4 & 31.0 & 32.0 & 31.8 & 32.2 \\
\hline $\mathrm{ADF}$ & 20.5 & 21.1 & 21.8 & 21.7 & 21.9 \\
\hline Starch & 31.5 & 30.1 & 27.1 & 29.2 & 25.7 \\
\hline NFC & 43.3 & 42.2 & 39.8 & 41.5 & 38.9 \\
\hline Ash & 7.1 & 6.8 & 7.0 & 6.9 & 7.3 \\
\hline $\mathrm{NE}_{\mathrm{L}}{ }^{1} \mathrm{Mcal} / \mathrm{kg}$ & 1.67 & 1.66 & 1.65 & 1.66 & 1.66 \\
\hline \multirow[t]{2}{*}{$\mathrm{RUP}^{2} \%$ of $\mathrm{CP}$} & 35.6 & 35.4 & 35.3 & 35.3 & 35.4 \\
\hline & 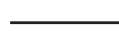 & \multicolumn{4}{|c|}{ (\% of sample remaining on screen [as-fed basis]) } \\
\hline$>19$ & 6.9 & 7.9 & 7.3 & 9.7 & 11.6 \\
\hline 8 to 19 & 45.9 & 46.8 & 47.9 & 43.9 & 41.7 \\
\hline$<8$ & 47.1 & 45.3 & 44.7 & 46.5 & 46.7 \\
\hline
\end{tabular}

\section{Intake and Digestibility}

Intake of DM, NDF, and starch during wk 5 was similar for all treatments (Table 4). Intake of $\mathrm{CP}$ was higher for 1.95 - vs. 2.54 -cm TLC $(P=0.05)$ and 8 - vs. 2 -mm KP $(P=0.006)$. Because there was no difference in DMI, differences in CP intake of KP diets were attributed to the increased percentage of $\mathrm{CP}$ in diets containing 2 - vs. 8 -mm KP silage (average $17.6 \%$ vs. $18.2 \%$, respectively). Others have reported no effect of TLC on CP intake (Dhiman et al., 2002; Johnson et al., 2002b).

Apparent digestibility of $\mathrm{DM}(P=0.02)$ and $\mathrm{ADF}(P=$ 0.005 ) was lower for 1.95 - than 2.54-cm TLC. Kuehn et al. (1997) and Johnson et al. (2003b) noted a tendency for DM digestibility to increase as chop length increased in corn silage. In contrast to the results of this trial, NDF digestibility has been reported to increase as TLC increases (Bal et al., 2000; Johnson et al., 2002b). Increasing TLC did not affect the apparent digestibility of starch, which is consistent with previous reports (Bal et al., 2000; Schwab et al., 2002).

Apparent digestibility of $\mathrm{NDF}(P=0.02)$ and $\operatorname{ADF}(P=$ 0.005 ) was lower for the diet containing the unprocessed corn silage compared with those containing KP corn silage. These results are consistent with previous research in which KP improved fiber digestion (Bal et al., 2000; Johnson et al., 2003a-experiment 2; Zobell et

Table 4. Nutrient intake and apparent digestibility of lactating Holstein cows fed diets containing corn silage chopped at different theoretical lengths of cut (TLC) with or without kernel processing (KP).

\begin{tabular}{|c|c|c|c|c|c|c|c|c|c|c|}
\hline & $\begin{array}{l}1.95-\mathrm{cm} \\
\text { TLC, } \\
\text { no KP }\end{array}$ & $\begin{array}{l}1.95-\mathrm{cm} \\
\text { TLC, } \\
2-\mathrm{mm} \mathrm{KP}\end{array}$ & $\begin{array}{l}1.95-\mathrm{cm} \\
\text { TLC, } \\
8-\mathrm{mm} \mathrm{KP}\end{array}$ & $\begin{array}{l}2.54-\mathrm{cm} \\
\text { TLC, } \\
2 \text {-mm KP }\end{array}$ & $\begin{array}{l}2.54-\mathrm{cm} \\
\text { TLC } \\
\text { 8-mm KP }\end{array}$ & $\mathrm{SE}$ & \multicolumn{4}{|c|}{ Contrast $^{1}$} \\
\hline \multicolumn{11}{|c|}{ Intake, $\mathrm{kg} / \mathrm{d}$} \\
\hline $\mathrm{CP}$ & 4.3 & 3.8 & 4.3 & 3.1 & 4.2 & 0.2 & 0.05 & NS & 0.006 & NS \\
\hline $\mathrm{NDF}$ & 6.8 & 8.0 & 7.4 & 6.4 & 7.1 & 0.4 & NS & NS & $\mathrm{NS}$ & NS \\
\hline $\mathrm{ADF}$ & 4.2 & 5.1 & 4.9 & 4.5 & 4.8 & 0.3 & NS & 0.08 & NS & NS \\
\hline DM & 52.7 & 48.6 & 54.3 & 59.2 & 52.8 & 1.7 & 0.02 & NS & NS & 0.003 \\
\hline $\mathrm{CP}$ & 59.3 & 50.8 & 62.6 & 57.9 & 60.1 & 2.2 & NS & NS & 0.006 & 0.05 \\
\hline $\mathrm{NDF}$ & 20.1 & 29.7 & 30.6 & 35.4 & 23.2 & 3.1 & NS & 0.02 & 0.10 & 0.07 \\
\hline $\mathrm{ADF}$ & 14.6 & 26.8 & 27.7 & 39.5 & 23.9 & 2.7 & 0.005 & 0.005 & 0.02 & 0.01 \\
\hline Starch & 79.4 & 83.1 & 75.8 & 87.7 & 75.3 & 1.8 & NS & NS & 0.0001 & NS \\
\hline
\end{tabular}

${ }^{1}$ Contrast includes 1) 1.95 - vs. 2.54-cm TLC, 2) unprocessed vs. KP, 3) 2- vs. 8-mm KP, and 4) interaction of TLC and KP (excluding the control).

${ }^{2} P>0.10$. 
Table 5. Dry matter intake, milk yield, milk composition, and plasma metabolites of lactating Holstein cows fed diets containing corn silage chopped at different theoretical lengths of cut (TLC) with or without kernel processing (KP).

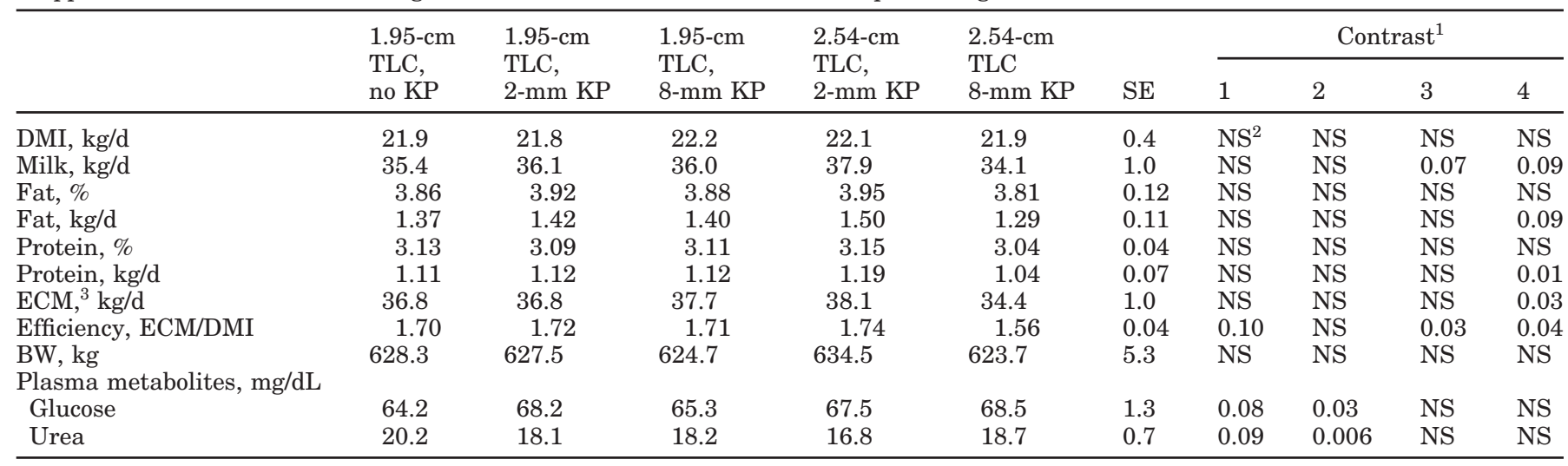

${ }^{1}$ Contrast includes 1) 1.95 - vs. 2.54-cm TLC, 2) control vs. KP, 3) 2- vs. 8-mm KP, and 4) interaction of TLC and KP (excluding the control). ${ }^{2} P>0.10$.

${ }^{3} \mathrm{ECM}=$ Energy-corrected milk.

al., 2002). The stover portion of the corn plant, as well as the grain, is crushed as it passes through the KP, increasing the surface area available for ruminal microorganisms to attach to and, thus, digestion. Apparent digestibility of starch was greater $(P<0.001)$ for diets containing silage processed at 2 vs. $8 \mathrm{~mm}(85.4 \%$ vs. $75.6 \%$, respectively) but was not affected by TLC. These data indicate that $\mathrm{KP}$ at $8 \mathrm{~mm}$ does not adequately crush or nick the kernel to increase starch digestion.

Apparent digestibility of DM was lowest for 1.95P, highest for $2.54 \mathrm{P}$, and intermediate for both $8-\mathrm{mm}$ treatments resulting in an interaction $(P=0.003)$. The apparent digestibility of $\mathrm{CP}$ was similar for all treatments except $1.95 \mathrm{P}$, which was lower resulting in an interaction $(P=0.05)$. An interaction was observed for ADF $(P=0.01)$ and NDF $(P=0.07)$ because of lower apparent digestibility for $1.95 \mathrm{P}$ and $2.54 \mathrm{M}$ compared with 1.95M and 2.54P. Young et al. (1998) hypothesized that increasing TLC for corn that had been processed should increase rumination time, thus increasing fiber digestion. The results of our trial indicate that increasing TLC from 1.95 to 2.54 does increase fiber digestibility for corn processed at $2 \mathrm{~mm}$. Processing at $8 \mathrm{~mm}$ does not appear to be adequate to improve fiber digestion.

\section{Production Response}

The DMI was similar for all treatments (Table 5). An interaction of TLC and KP was observed for milk yield $(P=0.09)$, yield of milk fat $(P=0.09)$ and protein $(P=$ $0.01)$, and ECM yield $(P=0.03)$ primarily because yields were lowest for cows fed $2.54 \mathrm{M}$ and highest with $2.54 \mathrm{P}$, whereas no differences were observed among $1.95 \mathrm{P}$ and $1.95 \mathrm{M}$. Because there were no differences in DMI, a similar interaction was observed for efficiency. No dif- ferences were observed in the percentage of milk fat or protein among treatments. No differences were observed in BW.

As TLC increased, concentrations of blood glucose tended to increase $(P=0.08)$ and urea nitrogen decreased $(P=0.09)$. Similarly, concentrations of glucose were higher $(P=0.03)$ and urea nitrogen lower $(P=$ $0.006)$ for processed vs. unprocessed corn silage.

These results are in agreement with the digestibility data. Apparent digestibility of fiber and starch were lowest for $2.54 \mathrm{M}$, which would have provided less total energy in support of milk and component synthesis. Although starch digestibility was also lower for $1.95 \mathrm{M}$, fiber digestibility was not depressed, which would have provided additional energy in support of milk synthesis.

Bal et al. (2000) noted an increase in milk yield of $1.2 \mathrm{~kg} / \mathrm{d}$ with corn silage $\mathrm{KP}$ at $1-\mathrm{mm}$ roll clearance compared with unprocessed silage, regardless of TLC. The increase in milk yield with aggressively KP corn silage is most likely related to increased starch digestibility for the 2 -mm processed silage.

\section{CONCLUSIONS}

Results of the current trial indicated that fiber and starch digestibility are improved only when corn harvested at three-quarter milk line is aggressively processed $(2 \mathrm{~mm})$. Less aggressive processing, especially as the TLC increases from 1.95 to $2.54 \mathrm{~cm}$, does not improve fiber or starch digestibility, resulting in lower energy available to support milk and component synthesis, and it decreases the efficiency of converting DMI to ECM. These results should be extrapolated to corn harvested at earlier stages of maturity as the impact on digestibility may not be as great. 


\section{ACKNOWLEDGMENTS}

The authors thank the Florida Milk Checkoff Program for partial funding and support of this research. We would also like to thank John Deere for use of the kernel processor and John Sykes and the farm crew for harvesting the crop. Deepest appreciation is also expressed to Heath Cross for his assistance on the farm and Melissa Tawzer for laboratory assistance.

\section{REFERENCES}

Association of Official Analytical Chemists. 1990. Official Methods of Analysis. 15th ed. AOAC, Washington, DC

Andrae, J. G., C. W. Hunt, G. T. Pritchard, L. R. Kennington, J. H. Harrison, W. Kezar, and W. Mahanna. 2001. Effect of hybrid, maturity, and mechanical processing of corn silage on intake and digestibility by beef cattle. J. Anim. Sci. 79:2268-2275.

Bal, M. A., R. D. Shaver, A. G. Jirovec, K. J. Shinners, and J. G. Coors. 2000. Crop processing and chop length of corn silage: Effects on intake, digestion, and milk production by dairy cows. J. Dairy Sci. 83:1264-1273.

Clark, P. W., and L. E. Armentano. 1999. Influence of particle size on the effectiveness of the fiber in corn silage. J. Dairy Sci. $82: 581-588$.

Cochran, R. C., D. C. Adams, J. D. Wallace, and M. L. Galyean. 1986. Predicting digestibility of different diets with internal markers: evaluation of four potential markers. J. Anim. Sci. 63:1476-1483.

Dhiman, T. R., M. A. Bal, Z. Wu, V. R. Moreira, R. D. Shaver, L. D. Satter, K. J. Shinners, and R. P. Walgenbach. 2000. Influence of mechanical processing on utilization of corn silage by lactating dairy cows. J. Dairy Sci. 83:2521-2528.

Dhiman, T. R., M. S. Zaman, I. S. MacQueen, and R. L. Boman. 2002. Influence of corn processing and frequency of feeding on cow performance. J. Dairy Sci. 85:217-226.

Doggett, C. G., C. W. Hunt, J. G. Andrae, G. T. Pritchard, W. Kezar, and J. H. Harrison. 1998. Effect of hybrid and processing on digestive characteristics of corn silage. J. Dairy Sci. 81(Suppl 1):761. (Abstr.)

Edmondson, A. J., I. J. Lean, L. D. Weaver, T. Farver, and F. Webster. 1989. A body condition scoring chart for Holstein dairy cows. J. Dairy Sci. 72:68-78.

Goering, H. K., and P. J. Van Soest. 1970. Forage Fiber Analysis. USDA Agricultural Research Service. Handbook number 379. U.S. Department of Agriculture. Superintendent of Documents, US Government Printing Office, Washington, DC.

Heinrichs, J. 1996. Evaluating particle size of forages and TMRs using the Penn State particle size separator. DAS 96-20. Pennsylvania State Univ. Coll. Agric. Sci.

Holm, J., I. Bjorck, A. Drews, and N. G. Asp. 1986. A rapid method for the analysis of starch. Starch/Die Starke. 7:224-226.

Johnson, L. M., J. H. Harrison, D. Davidson, C. Hunt, W. C. Mahanna, and K. Shinners. 2003a. Corn silage management: Effects of hybrid, maturity, chop length, and mechanical processing on rate and extent of digestion. J. Dairy Sci. 86:3271-3299.

Johnson, L. M., J. H. Harrison, D. Davidson, W. C. Mahanna, and K. Shinners. 2003b. Corn silage management: Effects of hybrid, chop length, and mechanical processing on digestion and energy content. J. Dairy Sci. 86:208-231.

Johnson, L. M., J. H. Harrison, D. Davidson, W. C. Mahanna, and K. Shinners. 2003c. Corn silage management: Effects of hybrid, maturity, inoculation, and mechanical processing on fermentation characteristics. J. Dairy Sci. 86:287-308.

Johnson, L. M., J. H. Harrison, D. Davidson, J. L. Robutti, M. Swift, W. C. Mahanna, and K. Shinners. 2002a. Corn silage management I: effects of hybrid, maturity, and mechanical processing on chemical and physical characteristics. J. Dairy Sci. 85:833-853.

Johnson, L. M., J. H. Harrison, D. Davidson, M. Swift, W. C. Mahanna, and K. Shinners. 2002b. Corn silage management II: Effects of hybrid, maturity, and mechanical processing on digestion and energy content. J. Dairy Sci. 85:2913-2927.

Johnson, L., J. H. Harrison, K. A. Loney, D. Bengen, R. Bengen, W. C. Mahanna, D. Sapienza, W. Kezar, C. Hunt, T. Sawyer, and M. Bieber. 1996. Effect of processing of corn silage prior to ensiling on milk production, component yield, and passage of corn grain into manure. J. Dairy Sci. 79(Suppl. 1):149. (Abstr.)

Kuehn, C. S., J. G. Linn, and H. G. Jung. 1997. Effect of corn silage chop length on intake, milk production, and rumen function in lactating dairy cows. J. Dairy Sci. 80(Suppl 1):219. (Abstr.)

National Research Council. 2001. Nutrient Requirements of Dairy Cattle. 7th rev. ed. Natl. Acad. Sci., Washington, DC.

Roberge, M., P. Savoie, and E. R. Norris. 1998. Evaluation of a crop processor in a pull-type forage harvester. ASAE paper no. 961029. ASAE, St. Joseph, MI.

Rojas-Bourrillon, A., J. R. Russell, A. Trenkle, and A. D. McGillard. 1987. Effects of rolling on the composition and utilization by growing steers of whole-plant corn silage. J. Anim. Sci. 64:303311.

SAS User's Guide: Statistics, Version 6 Edition, 1989. SAS Inst., Inc., Cary, NC.

Savoie, P. 1997. Kernel processing: History and engineering. Pages 85-94 in Proc. Silage: Field to Feedbunk. NRAES-99, NE Region Agric. Eng. Service, Ithaca, NY.

Schurig, M., and G. Rodel. 1993. Power consumption and the effect of corn crackers. ASAE paper no. 93-1586. ASAE, St. Joseph, MI.

Schwab, E. C., R. D. Shaver, K. J. Shinners, J. G. Lauer, and J. G. Coors. 2002. Processing and chop length effects in brown-midrib corn silage on intake, digestion, and milk production by dairy cows. J. Dairy Sci. 85:613-623.

Straub, R. J., R. G. Koegel, L. D. Satter, and T. J. Kraus. 1996. Evaluation of a corn silage processor. ASAE Int. Mtg., Paper No. 96-1033. ASAE, Phoenix, AZ.

Sudweeks, E. M., L. O. Ely, and L. R. Sisk. 1979. Effect of particle size of corn silage on digestibility and rumen fermentation. J. Dairy Sci. 62:292-296.

Weiss, W. P., and D. J. Wyatt. 2000. Effect of oil content and kernel processing of corn silage on digestibility and milk production by dairy cows. J. Dairy Sci. 83:351-358.

Young, M. A., T. J. Wistuba, B. E. Brent, L. H. Harbers, and K. K. Bolsen. 1998. The effect of processing corn silage on feedlot performance and nutrient digestibility in growing cattle. J. Anim. Sci. 81(Suppl. 1):199. (Abstr.)

Zobell, D. R., K. C. Olson, R. D. Wiedmeier, D. Sass, K. J. Shinners, and T. A. McAllister. 2002. Effects of processed corn silage on its digestibility and production of growing beef replacement heifers. Anim. Feed Sci. Technol. 96:221-228. 